\title{
Building Teacher Learning Climate through Improvement of Work Engagement
}

\author{
Anissa Lestari Kadiyono \\ Faculty of Psychology \\ Padjadjaran University \\ Bandung, Indonesia \\ anissa.lestari@unpad.ac.id
}

\author{
Serawanti Deliana \\ Faculty of Psychology \\ Padjadjaran University \\ Bandung, Indonesia \\ seradelianaa@gmail.com \\ Rezki Ashriyana Sulistiobudi \\ Faculty of Psychology \\ Padjadjaran University \\ Bandung, Indonesia \\ rezki.ashriyana@unpad.ac.id
}

\begin{abstract}
The purpose of this study is to provide an analysis to build teacher-learning climate through improvement of work engagement at teachers of public junior high school in Bandung. This research conducted to 109 respondents who actively teach in public junior high school in Bandung. Data collecting with simple random sampling. The results showed a positive correlation between teacher learning climate and work engagement. Engagement to their job will increase their perception to learn at school. This illustrates the efforts of teacher development in climate learning will improve the work of teachers in public junior high school in Bandung, so that will support efforts to improve the education of a good quality of human resources.
\end{abstract}

Keywords-teacher learning climate; work engagement; teacher; junior high school

\section{INTRODUCTION}

Education has a very important role for the civilization of the nation in order to give the nation's moral and prosperity. Therefore, a good quality of education is required in the Law with the aim of standardizing the system used in all parts of Indonesia to have national standards. According to Law (UU) No. 20 Year 2003 [1] referred to as the national education system are all components that are interrelated in an integrated manner to achieve national education objectives, based on Pancasila and UUD 1945, rooted in the values of religion, national culture of Indonesia, and responsive to the demands changing times. It is then re-enacted in the Government Regulation of the Republic of Indonesia No. 13 of 2015 on National Education Standards [2] which discusses the minimal criteria of the education system throughout the jurisdiction of the Unitary State of the Republic of Indonesia.

The regulations applied to all provinces in Indonesia which are adapted to the culture of each province. West Java Province is the province that has the most schools in Indonesia and recorded to have 29,543 schools [3]. As a province with the highest number of schools in Indonesia, West Java wants the implementation of education in its region of West Java Provincial Regulation. While the operational policy of the implementation of education is still carried out refers to the national standard policy.

Improving the quality of human resources becomes important because it is a factor driving other resources in the organization [4]. The empowerment of human resources is the main factor in identifying the efforts that can be done by the organization to improve its performance [5]. The development of human resources through the enhancement of self-potential owned is the most effective and most efficient way to improve overall organizational productivity [6]. The concept of empowerment of human resources can be discussed with the concept of teacher learning climate (TLC). Teacher Learning Climate is an effort to transform learning into sustainable growth (Marsick, Watkins, Callahan, \& Volpe, 2009 in [7]). In the other words, the climate is created to help teachers for learning and development. Teacher learning climate has seven dimensions: (1) create continuous learning opportunities is the opportunities for teachers from schools to grow and increase knowledge, (2) promote inquiry and dialogue is the discussing each other, giving feedback and support each other teachers in everyday teaching live, (3) encourage collaboration and team learning is the discussion forums from schools and government to facilitate teachers to exchange information, (4) create systems to capture and share learning that schools advancing teachers to keep abreast of technological and information developments with technology systems applied to the teacher learning environment, (5) empower people toward a collective vision is how the school environment mutually empower members to be able to unite achieve common goals, (6) connect the organization to its environment that is how schools empower all school members in making connections with their environment, and (7) provide strategic leadership for learning that has a leader who always provides insight for members within it to be able to support learning and achieve goals. 
The learning climate will be felt and be perceived by the teachers to identify how the atmosphere in the school encourages learning and provides opportunities for learning (Marsick \& Watkins in [7]). Perception is the interpretation of received sensory information as a whole into a real model that becomes a consideration in making decisions and act (Atkinson and Hilgard's in [8]). Perception that have been built by teachers will form a positive or negative evaluation in accordance with experience and meaning in them. Attitude is an evaluative reaction about an object, person, or event. If the learning climate that has been built by the school is considered to help teachers in learning and adjusting, it will create a positive attitude, if the learning climate that has been built by the school considered less help teachers in learning and adjusting will create a negative attitude.

Work engagement is a positive, fulfilling, work-related state of mindthat is charactericed by vigor, dedication, and absorption (Schaufeli, Salanova, Gonzales-Roma \& Bakker, 2002; in [9]).

The explanation as follows:

- Vigor, the feeling of excitement or strength in work that is marked by the teacher feel energetic at work, have the willingness to try and be able to face problems and difficulties, not easily tired and resilient despite difficulties in his work.

- $\quad$ Dedication, the feeling of dedication at work marked by the teacher feels strong involvement and experiences feelings of meaningfulness, enthusiasm, inspiration, pride, and challenge to his work.

- Absorption, the feeling of drowning at work marked by the teacher concentrating fully and seriously in doing a job, feeling happy about the job, and time feels so quickly passed and find it difficult to get away from his job.

Teachers who have work engagement, it will produce a good work performance. Positive mind conditions and positive feelings in work can trigger performance and achievement of the target in carrying out the mission of improving the quality of education in the city of Bandung Research conducted by Schaufeli and Salanova [10], showed social support, feedback, diverse abilities, and opportunities for learning and developing self will have a positive relationship with work engagement. Based on the research, if the learning climate that teachers feel is good, the teacher can be more engaged with his work with a positive state of mind and feeling characterized by feelings energetic, feelings of dedication, and absorp at work. Feelings of energetic or strength in work are shown by teachers who are not easy to complain and no easy to feel tired at work.

In the early data interview the teacher feel that they were proud and happy at the time of work, and persistently finished the job and resposibility. But in the early data still shows the majority of teachers who often experience the negative state of mind and negative feelings in work such as complaining, tired, saturated, lack of concentration. In fact, schools as an organization need members who feel energetic, dedicated, and engage with their work [11]. Several previous studies also say work engagement positively related to job performance [12]. Teachers at public junior high school in Bandung must have a good work engagement in order to improve performance and quality to achieve the purpose of Bandung in improving the quality of education.

Based on the phenomena that have been described above, it is known that the city of Bandung is on a mission to improve the quality of education aimed primarily for junior high school teachers. Changes in the education system provide a demand for teachers to continue to learn and develop themselves. In addition, teachers also have demands set forth in Government Regulation No. 7 of 2008 [13], which is to plan lessons, assess learning outcomes, guide and train learners, and carry out additional teacher tasks. Research about teacher learning climate becomes an important thing for the progress of education quality because it relates to how teachers perceive their learning environment. In relation to these demands, it requires support from a good work environment so teachers can be helped to face demands and have a positive state of mind and feeling in the work, and teachers can have a good work performance [14].

\section{RESEARCH METHODS}

The design of this study used a non-experimental quantitative approach, it is research that aims to obtain an accurate description of a situation or phenomenon [15]. The method used in this study is a correlational method that measures two variables and then determine the degree of relationship of the two variables [15]. While the data collection from this research was conducted using two questionnaires that measure teacher learning climate and work engagement.

Teacher learning climate measurement tool refers to instruments from Marsick and Watkins [16] that measure teachers's perceptions of teachers learning efforts by schools. The tools were distributed to respondents in the form of questionnaires including 18 items of statements with 6 alternative scales of answers from scale 1 (very rare) up to scale 6 (very often) with cronbach alpha reliability value of 0.890 . While the measuring tool of work engagement refers to instrument from Schaufeli and Bakker [17] which measures the state of mind and teachers feel when working. The instruments were distributed to respondents in the form of questionnaires including 30 items of statements with 7 alternative scale answers from scale 1 (never) to scale 7 (always) with Cronbach alpha reliability value of 0.928 .

Respondents in this study are teachers who actively teach in the period 2017/2018 at SMP Negeri (public junior high school) in Bandung. The population of teachers who are actively enrolled in teaching at SMPN Bandung city period 2017/2018 are 5400 teachers spread across 54 schools. This study used cluster random sampling technique, because the characteristic of the subject is homogeneous. Subject group in this study is determined based on the number of existing SMPN in the city of Bandung, which is $10 \%$ of 54 schools, so it can be determined 6 SMPN elected in the city of Bandung obtained by randomizing the list of 54 SMPN. In this study, the number of participating respondents is 109 teachers who are active in teaching and spread in six Junior High School at 
Bandung, they are SMPN 1, SMPN 2, SMPN 5, SMPN 9, SMPN 26, and SMPN 50.

\section{RESULT AND DISCUSSION}

Teacher Learning Climate is a school effort to transform learning into an integral part of work and provides opportunities for learning and sustainable growth [18], [7]. Teacher learning climate will be very instrumental in teachers to continue to learn and develop themselves to adjust to any changes to existing systems. The existing learning climate will be felt and then interpreted by the teacher to what extent the atmosphere in the school encourages learning and provides opportunities for learning (Marsick \& Watkins, 2003; in [7]). Based on the results of the research, the following results are obtained:

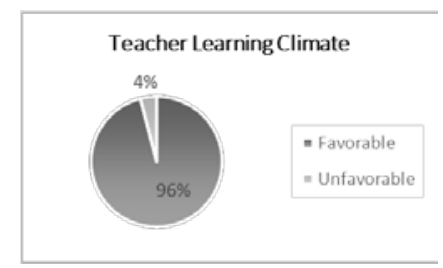

Fig. 1. Teacher Learning Climate

Based on the results of the data, it is obtained as much as $96 \%$ have a good perception of teacher learning climate at the school where the remaining $4 \%$ have a bad perception of teacher learning climate. This indicates that the majority of teachers at SMP Negeri in Bandung feel the effort of school in making learning environment and support of teacher's learning have already good. Teachers have been open to discuss with each other, give feedback, have opportunity to learn and develop, have collaborated in learning, mutually empowered to achieve common goals, have used technology systems for learning and develop themselves, have linked work with the environment, and already have leaders who support teacher learning and focus on achieving goals. But it can be seen that there are still few respondents who have unfavorable perception of learning climate in school.

Teacher Learning Climate Dimensions which have more loading factor to build Teacher Learning Climate is collaboration and team learning. The teachers of SMP Negeri in Bandung felt that the school and the government had facilitated the teachers by making the forums and programs so that the teachers could learn and discuss each other. Teachers also felt that they would be better able to pursue learning through the availability of these facilities. The teacher also acknowledges that the communication between the school teacher is better, and it becomes easier to exchange information and be confident in the outcome of the discussion.

The study shows that work engagement, positive and fulfilled state of mind associated with their work characterized by vigor, dedication, and absorption, shows the following results:

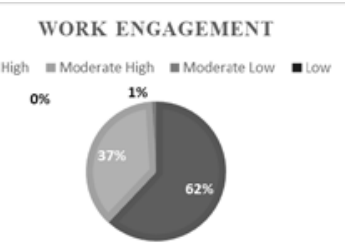

Fig. 2. Work Engagement

Based on data that have been processed from 109 respondents of SMP Negeri teachers in Bandung, it can be seen $62 \%$ of teachers are in high category which means the teachers have felt positive and fulfilled mind conditions in work characterized by every time feel high level of energy, every time dedicated, and every time feel absorp in their work. In addition, based on the diagram can be interpreted majority of teachers in SMP Negeri Bandung have moderate high work engagement. That means, teacher has positive and fulfilled mind at work which characterized by passionate to work, dedicated, and immersed in their job as a teacher of Junior High School at Bandung city.

Work engagement is important for schools especially junior high schools in Bandung who are having a mission to improve the quality of education. One such mission is to improve the quality and performance of teachers. Many studies suggest that workers who engage influence work, organizational success, and financial performance [19]. It is not surprising that many modern organizations require the need for vibrant workers and dedicate themselves to work [20]. The engaged workers have an energetic and effective relationship with their work activities, and see themselves able to confront job demands [21]. Good work engagement will result in good performance (Demerouti \& Bakker, 2006; in [9]). According to Saks [19], high work engagement also impact on organizational commitment. It was proven from teachers in Bandung State Junior High School who committed to his work, supported by low turnover and high dedication.

Teacher considers that they very proud to be a teacher, feels noble, honorable, great responsibility, and is indispensable in the sustainability of the nation in the future. A sense of dedication to the teacher is also demonstrated by teachers with a sense of pride in being a teacher because they think education is important and the key to everything that exists in the world.

Teacher at SMP Negeri in Bandung is a dedicated teacher in their work. They consider that their work is very meaningful and important to their lives. Because they think the teacher is a proud thing, and being a teacher is the goal of their lives. Thus, the positive involvement felt by the teachers can affect the outcomes of the work and predict the psychological well-being [22]. According to Beal, Weiss, Barros and MacDermid [23] if one considers his work as something interesting and important to them, as they feel their work is valuable, indispensable, noble, and so on. It makes it easier for people to allocate their resources.

Based on the correlation test, the following results are obtained: 
TABLE I. TEACHER LEARNING CLIMATE AND WORK ENGAGEMENT

\begin{tabular}{c|c|c}
\hline \multicolumn{2}{c}{ Work Engagement } \\
\hline $\begin{array}{c}\text { Teacher } \\
\text { Learning } \\
\text { Climate }\end{array}$ & Sig & $0.000^{*}$ \\
\cline { 2 - 3 } & Correlation coeeficient & 0.605 \\
\hline
\end{tabular}

Spearman test calculation results show the value of correlation coefficient (r) of 0.605 . This correlation coefficient has a value of significance (p-value) of 0.000 and positive value. The value of significance is then tested using a significance level of $0.05(\alpha=5 \%)$. Since 0.000 is smaller than 0.05 , there is a significant positive relationship between teacher learning climate and work engagement. Correlation value of both variables that have positive values indicate that the relationship is unidirectional, i.e. the better teacher learning climate will make better work engagement. To see the influence of teacher learning climate variables on work engagement, it can be used coefficient of determination in the form of the squared value of Spearman coefficient (r2). The coefficient of determination in this research is 0.3660 . This means that the ability of teacher learning climate variables in explaining work engagement at the State Junior High School Teachers of Bandung amounted to $36.6 \%$. The remaining $64.4 \%$ is explained by other factors. Other aspects that may affect work engagement include the demands of teacher's work, facilities provided by schools and government, and personal aspects of the teacher.

The results of the correlation it can be said that if teachers feel the school effort in making the learning environment and support the teacher's learning has been felt well and meet, it will lead to positive conditions and feelings in work. The correlation category between moderate teacher learning climate means that if teachers feel the school effort is better then it will be enough to contribute to the teacher to improve the quality.

As has been explained that $36.6 \%$ variation of work engagement can be influenced by teacher learning climate but $64.4 \%$ other influenced by other factors. Based on the Job Demands-Resources work engagement model (JD-R) model (Bakker \& Demerouti, 2007 in [11]), there are components that can affect the positive state of mind and feeling in work. First is the personal resources that are aspects of the self that are related to resilience and refer to the individual's sense of ability at work (Hobfoll, Johnson, Ennis \& Jackson, 2003; in [9]). Other factors in this study are the demands of teachers in work, job resources (in addition to teacher learning climate), as well as personal resources.

These job demands may indirectly affect the condition of the teacher's thoughts and feelings in working. In the face of these demands, the school's efforts (training resources, training, workshops, discussion programs, and so on) can help teachers to deal with it so that teachers can have positive feelings in the face of work and demands. Incentives from schools and government in the form of salary or bonus allowances, teacher work atmosphere in school, and support from colleagues can also affect the feelings of teachers in work.

Job demands will become more challenged to do when balanced with personal resources. Job demands are not a negative thing, but can be a stressor for teachers if there is no good resources for teachers. In connection with the existence of these components then the teacher can have a state of mind that concentrates, feelings of excitement, feelings of dedication, drowning in work and kiran conditions and other positive feelings that can be called work engagement. Work Engagement is a work-related, positive state of mind, characterized by vigor, dedication, and absorption (Schaufeli, Salanova, Gonzales-Roma \& Bakker, 2002; in [9]).

Teacher learning climate can be referred to as job resources because it will be able to reduce the demands of teacher's work, give influence to the achievement of goals, and stimulate the development and learning. If the efforts of schools and government in support of teachers' learning is felt to be good and meet the demands of work felt by many teachers will be reduced. Teacher learning climate will also stimulate teacher development and learning. Based on preliminary data obtained, the majority of teachers said they had received supportive learning opportunities, support from colleagues, technology-based learning, discussion forums and so on. In this study, the variables used are job resources that is teacher learning climate that is directly related to how the school efforts in supporting teacher learning in the face of changes in the education system in Bandung.

The job resources support of teacher learning provided by schools and government. The teacher's personal resources are also well characterized by the experience and good knowledge of the teacher. Given these things, although the demands (job demands) are felt a lot, it will still lead to a good work engagement, marked by the state of mind and feelings of a positive teacher in the work. That's because the resources (job and personal) are perceived good will reduce the job demands are many and will result in good work engagement. From this study it can be seen that, the majority of teachers of SMP Negeri Bandung have the view that the learning climate in schools that encourage their learning is sufficient and fulfilled. This means that SMP Negeri Kota Bandung has been able to meet the needs that support and encourage teachers to continue to learn and develop their ability to adjust the ability to changes that are marked by the availability of access and learning facilities of teachers, the existence of teacher discussion forums, support and these learning opportunities make teachers have a positive attitude to their work because of the feeling of being supported by the school. In accordance with the results of research conducted Bakker et al. [20] that the school efforts felt good teachers can help teachers adjust to the demands of their work and give a positive impact on the condition of the teacher's mind and feelings when working.

\section{CONCLUSIONS}

- There is a significant positive correlation between teacher learning climate and work engagement at public junior high school teachers in Bandung, with correlation included into moderate correlation. This shows that if 
schools and government can support teacher's learning and create wide teacher learning opportunity, it will be enough to contribute to the positive thoughts and feelings of teachers in work.

- Teacher learning climate of teachers at public junior high school in Bandung is in favorable category which indicates the teachers feel that the school effort has supported its learning.

- Work engagement of teachers at public junior high school in Bandung is in the high category. It shows that the teacher is already engaged with his work. With high-categorized work engagement, it means that teachers have felt a positive state of mind and positive feeling when working, which is characterized by having high level of energy and strength at work, a sense of dedication, and a feeling of absorption in their work.

- Suggestions that can be submitted based on this research is to know that a good teacher learning climate can improve the condition of positive thoughts and feelings when working. Thus, the learning opportunities provided by the school and government are important to follow such as forum for expanding the knowledge and skills that will help teachers adjust and improve their positive state of mind and feelings while working. Schools and government can also reduce the burden of workload for teachers.

\section{REFERENCES}

[1] Republic of Indonesia, Law no. 20 year 2003 about National Education System. [Online]. Available: http://kelembagaan.ristekdikti.go.id/wpcontent/uploads/2016/08/UU_no_20_th_2003.pdf. [Accessed May 13, 2017].

[2] Government of Indonesia, Government Regulation no. 13 year 2015 about National Standard of Education. [Online]. Available: http://pmp.dikdasmen.kemdikbud.go.id/files/peraturan/pp/PP_NO_13_2 015_Perubahan_kedua_PP19.pdf. [Accessed May 13, 2017].

[3] http://jendela.data.kemdikbud.go.id

[4] A. L. Kadiyono, "Pengaruh Human Capital Terhadap Positive Organizational Behavior Melalui Motivasi Kerja Dan Komitmen Organisasional Sebagai Mediator (Studi Empirik Pada Pegawai Divisi Marketing Di Bumn Bidang Jasa Wilayah Jawa Barat) [The Influences Of Human Capital To Positive Organizational Behavior Through Work Motivation And Organizational Commitment As Mediating Variables (The Empirical Study At Marketing Division Employees In The State Owned Enterprises Of Services Industry In West Java)]," PhD dissertation, Padjajaran Univ., 2011.

[5] A. L. Kadiyono and S. Sumantri, "Identifikasi Hambatan Organisasi Dalam Memberdayakan Sumber Daya Manusia Serta Hubungannya Dengan Kepuasan Kerja Karyawan [Identification of Organization's
Challenge to Empower Human Resources and its Relatons with Employee's Working Satisfactory],” Abstrak, 2010.

[6] A. L. Kadiyono, "Efektivitas Pengembangan Potensi Diri dan Orientasi Wirausaha dalam Meningkatkan Sikap Wirausaha [Effectivity of SelfPotential Development and Entrepreneurship Orientation in order to Improving Entrepreneurship Attitudes],” JIP: Jurn. Interven. Psikol., vol. 6, no. 1, pp. 25-38, 2014.

[7] A. Shoshani and L. Eldor, "The Informal Learning of Teachers: Learning Climate, Job Satisfaction and Teacher's and Students' Motivation and Well-Being,” Int. J. of Edu. Res., vol. 79, pp. 52-63, 2016.

[8] Nolen-Hoeksema, Atkinson \& Hilgard's Introduction to Psychology, 15th ed. United Kingdom: Cengage Learning EMEA, 2009.

[9] A. B. Bakker, Building engagement in the workplace. In R. J. Burke \& C.L. Cooper (Eds.), 2009.

[10] W. B. Schaufeli and M. Salanova, "Work engagement: An emerging psychological concept and its implications for organizations," In Research in social issues in management: Vol. 5. Managing social and ethical issues in organizations, S.W. Gilliland, D.D. Steiner \& D.P. Skarlicki (Eds.). Greenwich, CT: Information Age Publishers, 2007.

[11] A. B. Bakker and M. P. Leiter, "Where to go from here? Integration and future research on work engagement,” In Work engagement: A handbook of essential theory and research, A.B. Bakker and M.P. Leiter (Eds.). New York: Psychology Press, 2010.

[12] A. B. Bakker and E. Demerouti, “The Job Demands-Resources model: State of the art,” J. of Manageri. Psychol., vol. 22, pp. 309-328, 2007.

[13] Regional Regulations of West Java no. 7 year 2008 about Education Organization.

[14] A. B. Bakker, E. Demerouti, and W. Verbeke, "Using the Job Demands Resources model to predict burnout and performance," Hum. Resou. Manage., vol. 43, pp. 83-104, 2004.

[15] L. B. Christensen, Experimental Methodology. USA: Pearson Education, Inc., 2007.

[16] V. J. Marsick and K. E. Watkins, "Demonstrating the Value of an Organization's Learning Culture: The Dimensions of the Learning Organization,” Advan. in Developi. Hum. Resou., vol 5, no. 2, 2003.

[17] W. B. Schaufeli and A. B. Bakker, UWES Utrecht Work Engagement Scale: test manual. Department of Psychology, Utrecht University, 2003.

[18] V. J. Marsick, "Toward a unifying framework to support informal learning theory, research and practice,” J. of Workpl. Learn., vol. 21, no. 4, pp. 265-275, 2009.

[19] A. M. Saks, "Antecendent and Consequences in Employee Engagement,” J. of Manageri. Psychol., vol. 2, no. 7, pp. 600-619, 2006.

[20] A. B. Bakker et al., "Job Resource Boost Work Engagement, Particularly When Job Demand Are High,” J. of Edu. Psychol., vol. 99, no. 22, pp. 274-284, 2007.

[21] W. B. Schaufeli and A. B. Bakker, "Job demands, Job resources, and their relationship with burnout and engagement: a multi-sample study," J. of Organization. Behav., vol. 25, pp. 293-315, 2004.

[22] Burke, J. Ronald, and G. El-Kot, "Work engagement among managers and professionals in Egypt: Potential antecedents and consequences," Afr. J. of Econ. and Manage. Stud., vol. 1, no. 1, pp. 42-60, 2010.

[23] D. J. Beal, H.M. Weiss, E. Barros and S.M. MacDermid, “An episodic process model of affective influences on performance," J. of Appl. Psychol., vol. 90, pp. 1054-68, 2005. 